\title{
Urinary Arsenic Excretion as a Biomarker of Arsenic Exposure in Children
}

\author{
YAW-HUEI HWANG \\ Institute of Occupational Medicine \\ and Industrial Hygiene \\ College of Public Health \\ National Taiwan University \\ Taipei, Taiwan, Republic of China
}

\author{
ROBERT L. BORNSCHEIN \\ JOANN GROTE \\ WILLIAM MENRATH \\ SANDY RODA \\ Department of Environmental Health \\ College of Medicine \\ University of Cincinnati \\ Cincinnati, Ohio
}

\begin{abstract}
Urinary arsenic concentration has been used generally for the determination of exposure, but much concern has been raised over the most appropriate expression for urinary arsenic levels. In this study, we examined the influence of various adjustments of expressing urinary arsenic data. All children who were less than 72 mo of age and who were potty trained were invited to participate in the present study. Urine, soil, and dust samples were collected, and arsenic measurements were made. The geometric mean of speciated urinary arsenic among children who provided first-voided urine samples on 2 consecutive mornings was $8.6 \mu \mathrm{g} / \mathrm{l}$ (geometric standard deviation $=1.7, n=289$ ). Speciated urinary arsenic was related significantly to soil arsenic in bare areas $(p<.0005)$. Use of a single urine sample versus the average of two first-voided urine samples collected on 2 consecutive mornings did not significantly alter the relationship between environmental arsenic and urinary arsenic levels. Furthermore, none of the adjustments to urinary concentration improved the strength of correlation between urinary arsenic and soil arsenic levels. Concentration adjustments may not be necessary for urinary arsenic levels obtained from young children who provide first-void samples in the morning.
\end{abstract}

IN ADDITION TO the arsenic that is distributed naturally in air, water, soil, and food, arsenic exposure also results from some human environmental activities (e.g., mining and processing of metals). In epidemiological studies, occupational inhalation of arsenic has been associated with lung cancer. ${ }^{1-3}$ In addition, uptake of arsenic via ingestion is associated with several cancers (e.g., skin, liver, bladder, kidney). ${ }^{4-10}$ Risk assessment therefore becomes an important issue in the prevention of potential hazards from environmental arsenic exposure. In this type of assessment, correct measurement of exposure of arsenic is essential for the accurate determination of dose.

Urinary arsenic concentration has been used for de- termination of exposure and for estimation of health risks. Not only is a urine sample the most readily available biological medium for estimating exposure, but $75 \%$ of the ingested inorganic arsenic, mono-methyl arsenic (MMA), or di-methyl arsenic (DMA) is excreted in urine within $3 \mathrm{~d}$ after exposure. ${ }^{11-13}$ Several methods of hydration adjustment have been developed for the estimation of urinary concentrations of these exotic substances. ${ }^{14-19}$ Adjustment for urinary creatinine excretion is the most commonly used in published standards (e.g., biological exposure indices [BEI] of the American Conference of Governmental Industrial $\mathrm{Hy}$ gienists). ${ }^{14}$ Other methods, such as specific gravity adjustment and determination of timed excretion rate of 
substances in urine, have been developed and are used widely for exposure evaluations. ${ }^{15,16}$ In addition, several investigators have recently proposed that urinary flowadjusted creatinine ratio controls for the effect of urinary excretion rate on the urinary concentration. 17,18,20,21 Nonetheless, the most appropriate method for expressing urinary concentration remains a topic on which there is little agreement. Furthermore, most of the published literature is based on data from adults and not from children. Therefore, in this study we took the opportunity to evaluate urinary arsenic concentration adjustment methods, especially in children.

This study took place in Anaconda, Montana, in the summer of 1992 through the summer of 1993. We examined the influence of various methods of expressing urinary arsenic on the strength of association with environmental arsenic. For this purpose, we adjusted the urinary arsenic, based upon the most commonly used urinary adjustments. We compared these adjusted urinary arsenic concentrations with respect to their strengths of correlation with soil arsenic concentration. It was hypothesized that creatinine adjustment would best explain the variance in urinary arsenic levels.

\section{Material and Method}

The study area was the town of Anaconda, Montana, and the surrounding vicinity. Almost $100 \mathrm{y}$ of smelter operations produced waste materials, including tailings and flue dust, that now cover approximately 4000 acres. ${ }^{22}$ The entire smelter complex ceased operations in September 1980. In 1983, the Environmental Protection Agency placed this site on the Superfund National Priority List (NPL) for priority cleanup.

Prior to initiation of the current study, we undertook a door-to-door census in April and May, 1992, to determine how many families and children $(<72$ mo of age) were in the proposed study area. All families with ageappropriate and eligible children (i.e., $<72 \mathrm{mo}$ of age and potty trained) were invited to participate. The children had to have resided at their current addresses for at least 3 mo. Study participation was strictly voluntary. Following verbal and written descriptions of the study, we asked participants to sign an informed consent statement.

In addition to the initial census survey, we administered questionnaires during the study period to collect detailed individual and familial information on participating children's demographic and behavioral characteristics; participating families' socioeconomic status, residence location, housing condition, and housing history; and general environmental conditions with respect to potential arsenic exposure. At the times the monitoring team collected soil, dust, and urine samples, team members completed corresponding forms on which detailed collection information about each child-specific sample (e.g., date, time, place, area) was recorded.

Sample collection included soil, interior dust, and urine samples from study children. Exterior soil samples of the top $2 \mathrm{~cm}$ of soil were collected with a coring device. Five different types of soil samples were col- lected from each residential parcel occupied by the participating family. These five types of soil samples included the following perimeter soil samples collected from four sides of the residence; bare-area composite soil samples collected from all bare areas in a yard; gardenarea composite soil samples collected from all garden areas; if present, sand box or dirt play area samples; and gravel or hardpack drive/parking area samples. After air drying and sieving with a $250-\mu \mathrm{m}$ mesh, we used a Kevex Delta Analyst Energy Dispersive x-ray spectrometer to measure the arsenic in approximately $2 \mathrm{~g}$ of a loose soil sample.

Interior surface dust, which was collected in the residence in accordance with a previously developed method, ${ }^{23}$ was a composite of at least three subsamples taken from (a) an area adjacent to the main entrance, (b) a floor area in the room most used by the subject child, and (c) a floor area in the subject child's bedroom. The dried and weighed dust sample was processed for acid digestion with $7 \mathrm{~N}$ nitric acid and $1 \mathrm{~N}$ nitric acid, after which we submitted it for arsenic determination by a Perkin Elmer graphite furnace atomic absorption spectrometer (AAS).

The first-voided morning (FVM) urine samples were collected from each child participant on 2 consecutive d. After collection, we placed the sample and frozen blue ice in the small cooler. These samples were transferred later to a $125-\mathrm{ml}$ polyethylene bottle that contained nitric acid for acidification; the samples were then frozen for storage. A stratified random sample of 25 children drawn from the main study cohort was recruited, and these children provided 24-h urine samples. During this collection period, the children had to remain at home (i.e., on the property) for 24 h. During this $24-\mathrm{h}$ period, each child provided 3 urine samples: two samples were the first urine voids provided on 2 consecutive mornings (described earlier), and the third was designated as the mid-day urine sample. The third sample represented a composite of subsamples voided between the two consecutive first voids of the mornings.

At the field office, we analyzed urine samples for specific gravity by an optical refraction method. ${ }^{24}$ At the laboratory of Environmental Sciences Associates (ESA), researchers measured creatinine with a colorimetric method, using the Sigma Diagnostics Creatinine Kit. ${ }^{25}$ Routine urine sample analysis for arsenic was performed at the ESA laboratory. We used two methods to measure urinary arsenic. First, we used a modified digestion method to analyze total urinary arsenic, which includes inorganic arsenic, methylated arsenic, and fish arsenic (e.g., arsenobetaine, arsenocholine). ${ }^{26,27}$ The samples - which were acid digested with a mixture of nitric, perchloric, and sulfuric acids-were analyzed on a hydride-generation system attached to a flame AAS, Perkin-Elmer Model 2380 Flame AAS with a Perkin-Elmer MHS-10 [HG-FAAS]). We used the second method to determine combined $\mathrm{As}^{3+}, \mathrm{As}^{5+}$, monomethylarsonic acid (MMA), and dimethylarsinic acid (DMA), all of which are the major arsenic species and/or metabolites found in urine after exposure to inorganic 
arsenic, and they are referred to collectively as speciated urinary arsenic. These arsenic urinary compounds can be reduced by sodium borohydride and they produce a volatile hydride, whereas other organic arsenics cannot. ${ }^{28}$ Therefore, the analytical method for the speciated urinary arsenic was based on the direct analysis of the urine sample, which was pretreated with $3 \%$ sodium borohydride, on the HG-FAAS.

In this study, we applied the four most commonly used urinary concentration adjustment methods to compare the resulting expressions of urinary arsenic concentration that are described below.

1. Specific gravity adjustment, $\mathrm{AsU}_{\mathrm{SG}}(\mu \mathrm{g} / \mathrm{l}) .{ }^{15}$ For this method, we assumed that the excretion of xenobiotics and urinary solutes (i.e., producers of urine's specific gravity) was stable. Only the elimination rate of the solvent (water) differed. The purpose of the specific gravity adjustment method is to remove the effect that various hydration states have on the urinary concentration. All urinary concentrations are therefore adjusted to the same specific gravity for further comparison. The equation of this adjustment is as follows:

$$
\begin{aligned}
\mathrm{As}_{\mathrm{SG}}= & (\text { Urinary Arsenic } \times 0.020) /(\text { Specific Gravity } \\
& -1.000) .
\end{aligned}
$$

2. Creatinine adjustment, $\mathrm{AsU}_{\mathrm{CN}}(\mu \mathrm{g} / \mathrm{g}) .{ }^{19}$ Adjustment of urinary arsenic concentration to urinary creatinine excretion is accomplished simply by dividing the measured urinary arsenic concentration $(\mu \mathrm{g} / \mathrm{l})$ by urinary creatinine concentration $(\mathrm{g} / \mathrm{l})$, as shown below. Given that urinary volume is the denominator for both concentrations in this ratio, this volume factor is canceled out, and, therefore, the hydration effect need not be considered further.

$$
\mathrm{AsU}_{\mathrm{CN}}=(\text { Urinary Arsenic, } \mu \mathrm{g} / \mathrm{l}) /(\text { Creatinine, } \mathrm{g} / \mathrm{l}) \text {. }
$$

3. Timed excretion rate, $\mathrm{AsU}_{\mathrm{TE}}(\mu \mathrm{g} / 8 \mathrm{~h}) .{ }^{16}$ Timed excretion rates are typically calculated for a $24-\mathrm{h}$ period; this controls for any effects of diurnal rhythms. Nonetheless, 24-h urine collection is extremely inconvenient for research study subjects, and it is difficult to prevent the loss of some of the serial samples. In the present study, therefore, we used the first-voided urine sample of the morning to represent the sleeping period. The corrected timed excretion rate was calculated as shown below and was normalized to an 8-h period for purposes of comparison.

$$
\begin{aligned}
& \mathrm{AsU}_{\mathrm{TE}}=[(\text { Urinary Arsenic, } \mu \mathrm{g} / \mathrm{I}) \times(\text { Void Volume, } \mathrm{I}) \\
& \times 8 \text { h]/Elapsed Time Since Last Void, h. }
\end{aligned}
$$

4. Urinary flow rate adjusted creatinine ratio, $\operatorname{As}_{\mathrm{UF}}(\mu \mathrm{g} / \mathrm{l}) .{ }^{17,18}$ With respect to the urinary flow adjusted creatinine ratio for arsenic, both urinary arsenic concentration and urinary creatinine concentration should be adjusted to a urinary flow of $1 \mathrm{ml} / \mathrm{min}$, according to the formula $U^{*} V^{b}$, where $U=$ measured concentration and $V=$ urinary flow $(\mathrm{ml} / \mathrm{min}) .{ }^{17}$ These two adjusted concentrations form a ratio (as was the case for simple creatinine adjustment) that provides the urinary flow rate adjusted creatinine ratio. The equation for this calculation is as follows:

$$
\begin{aligned}
\text { As }_{\mathrm{UF}}= & (\text { Urinary Arsenic, } \mu \mathrm{g} / \mathrm{l} \div \text { Creatinine, } \mathrm{g} / \mathrm{l}) \\
& \times(\text { Urinary Flow Rate, } \mathrm{ml} / \mathrm{min})^{b_{1}-b_{2}} .
\end{aligned}
$$

Urinary flow rate $(\mathrm{ml} / \mathrm{min})$ was calculated as total void volume $(\mathrm{ml})$ divided by the elapsed time since last void (min). We calculated the $b_{1}$ and $b_{2}$ values, based on the dataset of 24-h urine samples, by the least squares method and in accordance with the following two equations ( $a_{1}$ and $a_{2}$ are intercepts for each regression line):

$$
\begin{aligned}
& \log (\text { Urinary Arsenic, } \mu \mathrm{g} / \mathrm{l}) \\
& =a_{1}-b_{1} \times \log (\text { Urinary Flow Rate, } \mathrm{ml} / \mathrm{min}), \\
& \log (\text { Creatinine, } g / l) \\
& =a_{2}-b_{2} \times \log (\text { Urinary Flow Rate, } \mathrm{ml} / \mathrm{min} \text { ). }
\end{aligned}
$$

We entered the data collected from questionnaires and results gleaned from laboratory analyses into the FoxBASE+/Mac database system on a Macintosh personal computer for storage and error checking..$^{29} \mathrm{We}$ used the Statistical Analysis System for Personal Computers (SAS-PC) $)^{30}$ to perform data analyses.

Given the log-normal distribution, we transformed urinary arsenic and environmental arsenic data to their log equivalents, and estimates of the sample geometric mean and geometric standard deviation were obtained. Simple bivariate correlations among the exposure variables and dependent variables were then calculated. We also performed correlational analysis between these four methods for adjusting urinary arsenic and soil arsenic concentrations for the purpose of examining the strength of association between each expression of urinary arsenic and soil arsenic. We assumed that the more the observed variance in urinary arsenic was explained by the environmental arsenic, the more valid the urinary adjustment method for expressing urinary arsenic levels.

We used a multiple regression analysis to find the most parsimonious model for predicting the urinary arsenic level. We used a backward stepwise process to select the important variables that contributed to the model. Model predictors included arsenic level in bare area soil; child's age, height, weight, gender, and body surface area; an index of hand-to-mouth behavior; urine specific gravity; and urine creatinine. Only variables significant at the .05 level remained in the final model.

\section{Results}

The results of the door-to-door census revealed a total of 480 families that contained 642 children who were less than 72 mo of age and who lived in or near Anaconda. Some families refused to participate or had moved prior to environmental sampling; therefore, only $412(85.8 \%)$ families participated in the present study. We recruited only age-appropriate potty-trained children for urine collection. Thus, 414 children in 334 families served as study subjects in the urine arsenic evaluation. 
As noted previously, we intended to collect urine samples on 2 consecutive $d$ to provide a more stable estimate of arsenic excretion. However, not all children provided first-voided urine samples on 2 consecutive mornings. Also, if a sample contained an abnormally low level of creatinine, indicative of a very dilute urine specimen, the arsenic result was excluded from analysis because the arsenic concentration might be spuriously low. In addition, the sample sizes of speciated urinary arsenic and total urinary arsenic in the data analysis might be different because there were difficulties encountered in each analytic process. As a result, urinary arsenic levels were available for 404 children. Of these 404 children, total and speciated urinary arsenic levels available on the 2 consecutive $d$ were obtained from 312 and 289 children, respectively. The intent was to perform statistical analyses based on firstvoided urine samples provided on 2 consecutive mornings; therefore, children who provided only one urine sample were excluded from the analyses. Nevertheless, there was no significant difference between the children who provided two urine samples and the excluded ones with respect to most demographic factors (e.g., height, weight, gender, race). Only the average age of the children who provided two urine samples $(52.6 \mathrm{mo})$ was slightly older than the average age of those who were excluded $(47.8 \mathrm{mo})$.

Descriptive data for recruited children who provided first-voided urine samples on 2 consecutive mornings are provided in Table 1. The body surface area of each child was determined from a nomogram, which was based on children's height and weight. ${ }^{31}$ With respect to the urine samples, the average volume of the first urine void of the morning was $54.4 \mathrm{ml}$ (standard deviation = $23.6 \mathrm{ml}$ ). The mean urinary creatinine and specific gravity were similar to those of the general population in this age range.

The results of the soil and dust arsenic measurements and urine arsenic levels are shown in Table 2. Soil arsenic levels were summarized for five sample types described previously. The geometric means of arsenic in different types of soil ranged from $121 \mu \mathrm{g} / \mathrm{g}$ to $236 \mu \mathrm{g} / \mathrm{g}$ (geometric standard deviations [GSDs] 1.9-2.3).
Perimeter soils and bare area soils in yards tended to have higher levels of arsenic contamination than soil samples collected in hardpack areas, garden areas, and play and/or sand box areas. Also shown in Table 2 is the interior dust arsenic level. A total of 477 interior dust samples were collected from the houses in the study area. The geometric mean of arsenic levels in all interior dust samples was $73 \mu \mathrm{g} / \mathrm{g}(G S D=1.84)$.

We determined total and speciated urinary arsenic levels for each urine sample and averaged the two consecutive urine samples for each child. Descriptive statistics for total urinary arsenic levels of 312 children are presented in Table 2. The geometric mean of total urinary arsenic for all children examined was $19.1 \mu \mathrm{g} / \mathrm{l}$ $(G S D=1.9)$. This level was slightly higher than that of children in the control communities of previous arsenic exposure studies $(17 \mu \mathrm{g} / \mathrm{l}) \mathrm{.}^{32}$ Results of speciated urinary arsenic analysis indicated that the geometric mean of speciated urinary arsenic was $8.6 \mu \mathrm{g} / \mathrm{l}(G S D=1.7)$. This mean level was less than that reported in the Tacoma study, in which the median of uncorrected speciated urinary arsenic for children aged 0-6 y was $15.0 \mu \mathrm{g} / \mathrm{l}^{33}$

A correlation coefficient matrix of the pertinent biological and environmental variables is shown in Table 3. This matrix evidences the simple relationships between arsenic exposure and urinary arsenic levels. Speciated urinary arsenic was correlated moderately with total urinary arsenic ( $r=.59)$. Correlations among arsenic concentrations in various environmental sample types (e.g., soil arsenic, dust arsenic) were moderate to strong (i.e., $r=.42$ to .77 ). Soil in bare areas in yards had the highest correlation with speciated urinary arsenic levels $(r=.25)$, whereas weaker correlations existed for the other four types of soil samples $(r=.12$ to .20$)$. Also, the correlations between soil arsenic levels and total urine arsenic were not significant. On the other hand, and in contrast to initial expectations, arsenic in interior dust did not correlate well with either type of urinary arsenic.

On the basis of first and second morning first-voided urine samples collected in the present study, we performed multiple regression analyses of various characterizations of urine arsenic levels (i.e., highest $[\mathrm{HIGH}$ -

Table 1.-Descriptive Statistics on Study Samples

\begin{tabular}{lcccc}
\hline \hline Variable & $\bar{x}$ & $S D$ & $\begin{array}{c}5 \text { th } \\
\text { percentile }\end{array}$ & $\begin{array}{c}\text { 95th } \\
\text { percentile }\end{array}$ \\
\hline Age $(\mathrm{mo})$ & 52.6 & 14.5 & 28.6 & 74.0 \\
Height $(\mathrm{cm})$ & 104.2 & 10.6 & 88.3 & 121.3 \\
Weight $(\mathrm{kg})$ & 16.5 & 3.6 & 11.4 & 22.7 \\
Gender $(\%$ male) & 48.3 & & & \\
Race $(\%$ white) & 97.4 & 0.123 & 0.515 & 0.895 \\
Body surface area $\left(\mathrm{m}^{2}\right)$ & 0.704 & 23.6 & 17.0 & 94.0 \\
First morning void $(\mathrm{ml})$ & 54.4 & 0.396 & 0.480 & 1.800 \\
Creatinine (g/l) & 1.092 & 0.005 & 1.017 & 1.033 \\
Specific gravity & 1.026 & & & \\
& & & &
\end{tabular}

Note: $N=271$ children. Only children with complete data for all nine variables are presented. 
EST], lowest [LOWEST], two consecutive urine sample average [AVERAGE], and day 1 [DAY 1] and day 2 [DAY 2] urine datasets). Although we included nine variables in the original model, only four variables were retained after backward elimination. The following is the best-fitted regression model with the selected variables:

$\ln$ (Speciated Urinary Arsenic)

$=\alpha+\beta_{1} \ln$ (soil arsenic level in bare areas in yards)

$+\beta_{2}$ child's body surface area

$+\beta_{3} \ln$ (urinary creatinine)

$+\beta_{4}$ child's hand-to-mouth behavior index.

The parameter estimates for different urinary arsenic characterizations are shown in Table 4. The intercept, slope for each predictor, and percentage of explained variance for each model are provided. According to the slope values and the standard errors in the parentheses, these slopes did not differ significantly from one other for any of the predictors nor was there a significant difference among the intercepts of these regression lines. Also, the percentages of explained variance $\left(r^{2}\right)$ in these regression models were very similar to one another. The results suggest that, when evaluating the relationship between speciated urinary arsenic and arsenic exposure variables, use of the highest, the lowest, the 2 consecutive day average, the day 1 or the day 2 of urine samples, does not affect the final result of the relationship studied. Thus a single first-voided morning sample may be sufficient for the characterization of large pop- ulations. Therefore, we used only the AVERAGE urinary arsenic to show the descriptive statistics of the unadjusted and adjusted total and speciated urinary arsenic concentrations (Table 5). Whereas the mean urinary arsenic concentration varied according to the adjustment method used, the geometric standard deviations of various expressions of urinary arsenic concentration did not differ much from one another, except for the geometric standard deviations of the corrected time-

Table 2.-Arsenic Measurements in Soil, Dust, and Urine Samples

\begin{tabular}{lccc}
\hline \hline Sample/area & $n$ & GM & GSD \\
\hline Soil sample arsenic $(\mu \mathrm{g} / \mathrm{g})$ & & & \\
$\quad$ Perimeter area & 435 & 236 & 1.9 \\
$\quad$ Bare area & 373 & 229 & 1.9 \\
$\quad$ Hardpack area & 237 & 121 & 2.2 \\
$\quad$ Garden area & 184 & 167 & 2.3 \\
$\quad$ Sandbox area & 354 & 177 & 2.3 \\
Interior dust sample & 477 & 73 & 1.8 \\
$\quad \begin{array}{l}\text { arsenic ( } \mu \text { g/g) } \\
\text { Total urinary arsenic }(\mu \mathrm{g} / \mathrm{l})\end{array}$ & 312 & 19.1 & 1.9 \\
$\quad$ Average & 312 & 23.5 & 2.0 \\
$\quad$ Highest & & & \\
Speciated urinary arsenic $(\mu \mathrm{g} / \mathrm{l})$ & 289 & 8.6 & 1.7 \\
$\quad$ Average & 289 & 10.4 & 1.8 \\
$\quad$ Highest & & & \\
\hline
\end{tabular}

Table 3.-Correlation Coefficient Matrix of Urinary Arsenic, Soil Arsenic, and Interior Dust Arsenic

\begin{tabular}{|c|c|c|c|c|c|c|c|}
\hline & $\begin{array}{c}\text { Total } \\
\text { urinary } \\
\text { arsenic }\end{array}$ & $\begin{array}{l}\text { Speciated } \\
\text { urinary } \\
\text { arsenic }\end{array}$ & $\begin{array}{c}\text { Perimeter } \\
\text { area soil } \\
\text { arsenic }\end{array}$ & $\begin{array}{c}\text { Bare area } \\
\text { soil } \\
\text { arsenic }\end{array}$ & $\begin{array}{c}\text { Hardpack } \\
\text { area soil } \\
\text { arsenic }\end{array}$ & $\begin{array}{l}\text { Garden } \\
\text { area soil } \\
\text { arsenic }\end{array}$ & $\begin{array}{c}\text { Sandbox } \\
\text { area soil } \\
\text { arsenic }\end{array}$ \\
\hline \multicolumn{8}{|l|}{$\begin{array}{l}\text { Total urinary } \\
\quad \text { arsenic }(\mu \mathrm{g} / \mathrm{l})\end{array}$} \\
\hline $\begin{array}{l}\text { Speciated urinary } \\
\text { arsenic }(\mu \mathrm{g} / \mathrm{l})\end{array}$ & $\begin{array}{l}0.59^{*} \\
(282)\end{array}$ & & & & & & \\
\hline $\begin{array}{l}\text { Perimeter area soil } \\
\text { arsenic }(\mu \mathrm{g} / \mathrm{l})\end{array}$ & $\begin{array}{l}0.04 \\
(282)\end{array}$ & $\begin{array}{l}0.17 t \\
(260)\end{array}$ & & & & & \\
\hline $\begin{array}{l}\text { Bare area soil } \\
\text { arsenic }(\mu \mathrm{g} / \mathrm{l})\end{array}$ & $\begin{array}{l}0.00 \\
(243)\end{array}$ & $\begin{array}{l}0.25^{*} \\
(226)\end{array}$ & $\begin{array}{l}0.77^{*} \\
(404)\end{array}$ & & & & \\
\hline $\begin{array}{l}\text { Hardpack area soil } \\
\text { arsenic }(\mu \mathrm{g} / \mathrm{l})\end{array}$ & $\begin{array}{r}-0.09 \\
(146)\end{array}$ & $\begin{array}{l}0.20 t \\
(134)\end{array}$ & $\begin{array}{l}0.60^{*} \\
(256)\end{array}$ & $\begin{array}{l}0.67^{*} \\
(224)\end{array}$ & & & \\
\hline $\begin{array}{c}\text { Garden area soil } \\
\text { arsenic }(\mu \mathrm{g} / \mathrm{l})\end{array}$ & $\begin{array}{l}0.10 \\
(132)\end{array}$ & $\begin{array}{l}0.20 t \\
(121)\end{array}$ & $\begin{array}{l}0.64^{*} \\
(202)\end{array}$ & $\begin{array}{l}0.55^{*} \\
(165)\end{array}$ & $\begin{array}{l}0.52^{*} \\
(112)\end{array}$ & & \\
\hline $\begin{array}{l}\text { Sandbox area soil } \\
\text { arsenic }(\mu \mathrm{g} / \mathrm{l})\end{array}$ & $\begin{array}{l}0.01 \\
(280)\end{array}$ & $\begin{array}{l}0.12 t \\
(257)\end{array}$ & $\begin{array}{l}0.65^{*} \\
(389)\end{array}$ & $\begin{array}{l}0.64^{*} \\
(335)\end{array}$ & $\begin{array}{l}0.50^{*} \\
(206)\end{array}$ & $\begin{array}{l}0.56^{*} \\
(172)\end{array}$ & \\
\hline $\begin{array}{l}\text { Interior dust } \\
\quad \text { arsenic }(\mu \mathrm{g} / \mathrm{l})\end{array}$ & $\begin{array}{l}0.01 \\
(310)\end{array}$ & $\begin{array}{l}0.03 \\
(286)\end{array}$ & $\begin{array}{l}0.45^{*} \\
(470)\end{array}$ & $\begin{array}{l}0.47^{*} \\
(404)\end{array}$ & $\begin{array}{l}0.47^{*} \\
(256)\end{array}$ & $\begin{array}{l}0.42^{*} \\
(203)\end{array}$ & $\begin{array}{l}0.52 * \\
(391)\end{array}$ \\
\hline
\end{tabular}

Notes: All variables had been log-transformed before correlation analysis; sample sizes appear within parentheses. ${ }^{*} p<.0005$.

$+p<.05$. 
excretion rates for both total and speciated urinary arsenic. Perhaps this occurred because the adjustment method involved two factors (i.e., urine volume and elapsed time), as well as urine arsenic concentration in its equation, whereas each of the other three methods involved only one factor. The involvement of more factors in the equation may have increased the variability of the derived data and the resulting geometric standard deviations.

The correlation coefficients of various forms of corrected urinary arsenic concentrations and other pertinent variables in this study are shown in Table 6. Logtransformed speciated urinary arsenic levels, either corrected or not corrected, were more correlated with soil arsenic than were total urinary arsenic levels. On the other hand, explained variance in urinary arsenic after these adjustments did not increase as expected. Generally, various procedures of adjustment on arsenic levels did not improve correlations between urinary arsenic and environmental arsenic levels.

\section{Discussion}

It has been reported that $45 \%-85 \%$ of arsenic ingested in the human body is excreted in urine within 1-3 d. ${ }^{11-13}$ Thus, urinary arsenic is considered a reliable internal biomarker for recent arsenic exposure. Inorganic arsenic, rather than organic arsenic, is considered to be the toxic form of arsenic; therefore, the metabolites of inorganic arsenic in urine ("speciated urinary arsenic") are of prime interest.

The present study contained several features that maximized the probability that the highest urinary arsenic levels would be observed, that the highest arsenic sources would be detected, and that the relationship between environmental sources and urinary arsenic be characterized correctly. As was mentioned earlier, the recruitment strategy focused on young children who were less than $72 \mathrm{mo}$ of age (average $=52.6$ mo) - a group known to be at greatest risk for elevated arsenic exposure. Urinary arsenic sampling was carried out during the summer, a time when seasonal factors combined to yield the highest urinary arsenic levels. The focus of measurement was on those sources and forms of arsenic that were immediately accessible to a young child (e.g., arsenic in interior house dust, in soil of bare areas in yards, in soil around the house perimeter, in sand box and/or play area soil). During the course of analyzing samples for arsenic content, attention was focused on that fraction of the environmental source

Table 4.-Comparison of Regression Models

\begin{tabular}{|c|c|c|c|c|c|c|}
\hline \multirow[b]{2}{*}{$\begin{array}{l}\text { Speciated } \\
\text { _As }\end{array}$} & \multirow[b]{2}{*}{$\begin{array}{l}\text { Intercept } \\
(\alpha)\end{array}$} & \multicolumn{4}{|c|}{ Slopes $(\beta)$} & \multirow[b]{2}{*}{$r^{2}$} \\
\hline & & $\begin{array}{c}\text { Body } \\
\text { size } \\
\left(\mathrm{cm}^{2}\right)\end{array}$ & $\begin{array}{l}\text { Hand_mouth } \\
\text { (freq./wk) }\end{array}$ & $\begin{array}{c}\text { Creatinine } \\
(\mathrm{g} / \mathrm{l})\end{array}$ & $\begin{array}{c}\text { Soil_B } \\
(\mu \mathrm{g} / \mathrm{l})\end{array}$ & \\
\hline Highest & $\begin{array}{c}2.29 \\
(0.32)\end{array}$ & $\begin{array}{l}-1.45 \\
(0.27)\end{array}$ & $\begin{array}{c}0.09 \\
(0.02)\end{array}$ & $\begin{array}{c}0.65 \\
(0.08)\end{array}$ & $\begin{array}{c}0.18 \\
(0.04)\end{array}$ & 0.35 \\
\hline Lowest & $\begin{array}{l}2.06 \\
(0.34)\end{array}$ & $\begin{array}{l}-1.51 \\
(0.28)\end{array}$ & $\begin{array}{c}0.08 \\
(0.02)\end{array}$ & $\begin{array}{c}0.55 \\
(0.07)\end{array}$ & $\begin{array}{c}0.17 \\
(0.05)\end{array}$ & 0.34 \\
\hline Average & $\begin{array}{l}2.10 \\
(0.33)\end{array}$ & $\begin{array}{l}-1.32 \\
(0.27)\end{array}$ & $\begin{array}{c}0.09 \\
(0.02)\end{array}$ & $\begin{array}{c}0.41 \\
(0.07)\end{array}$ & $\begin{array}{c}0.19 \\
(0.05)\end{array}$ & 0.30 \\
\hline Day 1 & $\begin{array}{l}2.06 \\
(0.34)\end{array}$ & $\begin{array}{l}-1.39 \\
(0.28)\end{array}$ & $\begin{array}{c}0.08 \\
(0.02)\end{array}$ & $\begin{array}{c}0.63 \\
(0.07)\end{array}$ & $\begin{array}{c}0.19 \\
(0.05)\end{array}$ & 0.36 \\
\hline Day 2 & $\begin{array}{c}2.54 \\
(0.35)\end{array}$ & $\begin{array}{l}-1.78 \\
(0.29)\end{array}$ & $\begin{array}{c}0.09 \\
(0.03)\end{array}$ & $\begin{array}{c}0.78 \\
(0.08)\end{array}$ & $\begin{array}{c}0.15 \\
(0.05)\end{array}$ & 0.40 \\
\hline
\end{tabular}

Notes: Intercept and slopes for each model are shown, and standard errors appear within parentheses. All intercepts and slopes for each model were significant at $p<.005$. We compared the regression models by using the highest, the lowest, the 2 -consecutive-day average, and the day 1 and day 2 datasets for speciated arsenic.

Table 5.-Descriptive Statistics for Uncorrected and Corrected Urinary Arsenic Concentrations

\begin{tabular}{|c|c|c|c|c|c|c|c|c|}
\hline \multirow[b]{2}{*}{$\begin{array}{l}\text { Corrected } \\
\text { urinary arsenic }\end{array}$} & \multicolumn{4}{|c|}{ Total_As $(n=287)$} & \multicolumn{4}{|c|}{ Speciated_As $(n=263)$} \\
\hline & $G M$ & GSD & $\begin{array}{l}\text { 5th } \\
\text { percentile }\end{array}$ & $\begin{array}{c}\text { 95th } \\
\text { percentile }\end{array}$ & $G M$ & GSD & $\begin{array}{c}5 \text { th } \\
\text { percentile }\end{array}$ & $\begin{array}{c}95 \text { th } \\
\text { percentile }\end{array}$ \\
\hline $\mathrm{As} \cup(\mu \mathrm{g} / \mathrm{l})$ & 19.2 & 1.9 & 7.0 & 63.0 & 8.6 & 1.7 & 4.0 & 23.0 \\
\hline $\mathrm{As}_{\mathrm{SG}}(\mu \mathrm{g} / \mathrm{I})$ & 17.9 & 1.8 & 7.0 & 47.0 & 8.3 & 1.8 & 3.0 & 21.0 \\
\hline $\mathrm{AsU}_{\mathrm{CN}}(\mu \mathrm{g} / \mathrm{g})$ & 12.5 & 1.8 & 5.0 & 32.5 & 5.8 & 1.8 & 2.6 & 15.3 \\
\hline $\mathrm{As}_{\mathrm{TE}}(\mu \mathrm{g} / 8 \mathrm{hr})$ & 0.54 & 2.3 & 0.14 & 1.72 & 0.27 & 2.0 & 0.08 & 0.73 \\
\hline $\mathrm{AsU}_{U F}(\mu \mathrm{g} / \mathrm{l})$ & 19.0 & 1.8 & 7.8 & 50.2 & 8.8 & 1.8 & 3.5 & 22.5 \\
\hline
\end{tabular}


Table 6.-Correlation Coefficients of Corrected Urinary Arsenic and the Study Variables

\begin{tabular}{|c|c|c|c|c|c|c|c|c|c|}
\hline & $\begin{array}{c}\text { Soil__ } \\
\mathrm{B}^{*}\end{array}$ & Age & Height & Weight & $\begin{array}{l}\text { Body } \\
\text { size }\end{array}$ & $\begin{array}{l}\text { Hand- } \\
\text { mouth* }\end{array}$ & Gender & $\underset{\text { gravity }}{\mathrm{Sp}_{-}}$ & Creatinine* \\
\hline \multicolumn{10}{|c|}{ Speciated urinary arsenic $(n=205)$} \\
\hline $\begin{array}{l}\mathrm{AsU}^{*} \\
\mathrm{AsU}_{\mathrm{SG}}{ }^{*} \\
\mathrm{AsU}_{\mathrm{CN}^{*}} \\
\mathrm{AsU}_{\mathrm{TE}}{ }^{*} \\
\mathrm{AsU}_{\mathrm{UF}^{*}}\end{array}$ & $\begin{array}{l}.28 t \\
.24 t \\
.21 t \\
.20 t \\
.20 t\end{array}$ & $\begin{array}{l}-.25 t \\
-.32 t \\
-.44 t \\
-.11 \\
-.47 t\end{array}$ & $\begin{array}{l}-.26 t \\
-.32 t \\
-.44 t \\
-.09 \\
-.47 t\end{array}$ & $\begin{array}{l}-.26 t \\
-.30 t \\
-.39 t \\
-.09 \\
-.43 t\end{array}$ & $\begin{array}{l}-.28 t \\
-.33 t \\
-.43 t \\
-.11 \\
-.47 t\end{array}$ & $\begin{array}{l}.28 t \\
.28 t \\
.32 t \\
.19 \S \\
.31 t\end{array}$ & $\begin{array}{l}.02 \\
.05 \\
.08 \\
.09 \\
.07\end{array}$ & $\begin{array}{c}.19 \S \\
\mathrm{NA} \\
-.34 \dagger \\
.18 \S \\
-.36 \dagger\end{array}$ & $\begin{array}{l}.26 t \\
-.09 \\
\text { NA } \\
.29 t \\
\text { NA }\end{array}$ \\
\hline \multicolumn{10}{|c|}{ Total urinary arsenic $(n=222)$} \\
\hline $\begin{array}{l}\text { AsU* } \\
\text { AsU }_{S G^{*}} \\
\text { AsU }_{\mathrm{CN}^{*}} \\
\text { AsU }_{\mathrm{TE}^{*}} \\
\text { As }_{\mathrm{UF}^{*}}\end{array}$ & $\begin{array}{l}.01 \\
.08 \\
.05 \\
.03 \\
.05\end{array}$ & $\begin{array}{l}-.13 \S \\
-.26 \dagger \\
-.40 \dagger \\
-.04 \\
-.40 \dagger\end{array}$ & $\begin{array}{l}-.13 \S \\
-.24 t \\
-.38 t \\
-.04 \\
-.38 t\end{array}$ & $\begin{array}{l}-.13 \S \\
-.21 \neq \\
-.34 t \\
-.05 \\
-.35 \dagger\end{array}$ & $\begin{array}{l}-.13 \S \\
-.23 t \\
-.37 t \\
-.05 \\
-.37 t\end{array}$ & $\begin{array}{l}.18 \S \\
.26 t \\
.29 t \\
.12 \\
.29 t\end{array}$ & $\begin{array}{r}-.02 \\
.00 \\
.04 \\
-.01 \\
.03\end{array}$ & $\begin{array}{c}.29 \dagger \\
\mathrm{NA} \\
-.20 \neq \\
.32 \dagger \\
-.19 \neq\end{array}$ & $\begin{array}{l}.32+ \\
-.09 \\
\text { NA } \\
.40+ \\
\text { NA }\end{array}$ \\
\hline \multicolumn{10}{|c|}{$\begin{array}{l}\text { Note: } N A=\text { not appropriate. } \\
\text { *Log-transformed. } \\
+p<.0005 \\
\neq p<.005 \\
\$ p<.05\end{array}$} \\
\hline
\end{tabular}

thought to produce the greatest risk to the child (i.e., arsenic in small particles $[<250 \mu \mathrm{m}]$ found in surface soil and dust that most readily adhered to hands and toys) and that could be ingested inadvertently. In general, the present study, which contained these features, offered us the best opportunity to evaluate the relationship between environmental arsenic levels and the internal dose of children with arsenic exposure. Estimates of the impact of various independent variables (soil arsenic, dust arsenic, etc.) could be developed, using regression techniques. Thus, with a sufficiently wide range of exposure, which encompassed background exposure levels, we could obtain estimates of the impact of environmental arsenic sources via data derived from within the study areas. The effects of various urinary concentration adjustments can, therefore, be evaluated well.

Even though we demonstrated that soil arsenic levels were correlated significantly with urinary arsenic concentration, the percentage of explainable variance in urinary arsenic was low. This situation might be attributed to the arsenic sources other than soil and dust, as well to the low urinary arsenic levels found in the study area. Not all arsenic in urine originated from mining-related activities. Some undefined fraction of arsenic also originated from dietary arsenic (i.e., water and food), whereas arsenic exposure via inhalation and skin contact may have been alternative pathways for the environmental sources. In the study area, the air arsenic level was quite stable and was well below the national average level for remote areas. ${ }^{34}$ Based upon an average air arsenic concentration of $0.0021 \mu \mathrm{g} / \mathrm{m}^{3}$ during the year prior to the present study, we calculated that the amount of estimated respiratory arsenic accounted for only $0.7 \%$ of the average daily arsenic excreted in urine for children aged
24-72 mo. The value is so small that its contribution to urine arsenic may be neglected. With regard to water arsenic, the measured water arsenic level was $1.36 \mu \mathrm{g} / \mathrm{l}$ in the municipal water-supply system, which supplied $81.3 \%$ of the households studied. Most of the water arsenic levels in private wells were below $5 \mu \mathrm{g} /$ l (average $=2.5 \mu \mathrm{g} / \mathrm{l}$ ). Despite the fact that concentrations were low, water arsenic accounted for a significant portionabout $21 \%-45 \%$ of the children's daily speciated urinary arsenic output-in the present study. However, we considered the arsenic that tap water contributed to total arsenic intake to be reflected in background urinary arsenic levels-and not as the primary factor-for the explanation of differences in speciated urinary arsenic levels among the study children. The low urinary arsenic levels found in the study area were likely a reflection of low availability of some forms of arsenic in contaminated soil. The results of recent micro-analysis of soil particles in the residential study area, for which an electron beam microprobe was used, suggested limitations of bioavailability ${ }^{35}$ of arsenic derived from mine mill and smelter waste present in residential soils. A recently completed animal feeding study provided further evidence of low bioavailability of arsenic found in Anaconda soils. ${ }^{36}$ The results also indicated that arsenic in this kind of soil was likely to occur in a less-soluble form and was, therefore, less absorbable than sodium arsenate. These factors likely accounted for the relatively low percentage of variance in urinary arsenic explained by the environmental soil arse- nic levels.

Urinary concentrations of exotic chemicals vary over a wide range. Each xenobiotic may need correction by a specific adjustment method, thus enabling examination of the relationship to external exposure levels. Improvements in methods of urinary concentration 
adjustment have increased the reliability of this biological monitoring process; however, no clear standard exists for the correction of varying effects of urinary flow, dilution, and elapsed time of void. Among urinary concentration adjustment methods developed to date, we chose four of the most commonly used methods to correct the urinary arsenic concentration in the present study, and we compared the effect of each adjustment on the strength of association between environmental arsenic exposure and corrected urinary arsenic concentrations. None of them, however, improved the strength of this association significantly.

Creatinine and specific gravity are the most commonly used urinary concentration adjustments in clini$\mathrm{cal}$ and industrial hygiene studies. Both of these adjustments attempt to correct for the variation in degree of hydration. ${ }^{14,37}$ It is assumed that creatinine is excreted at a constant rate; therefore, we assume further that creatinine can be used to normalize untimed urine samples to the amount of creatinine found in a given volume of urine. Nonetheless, creatinine excretion may vary with many factors (e.g., diurnal variation, body mass, age, gender, health, diuresis [urine flow], drug and alcohol use, diet, exercise). ${ }^{38}$ Similarly, specific gravity adjustment may be a convenient surrogate for timed samples, but it also suffers the same problems as does creatinine adjustment. Thus, both adjustments appear to be relatively imprecise for the reflection of substance concentrations. The present study provided supporting evidence for this viewpoint inasmuch as neither adjustment improved the strength of association between urinary arsenic and soil arsenic.

The third adjustment method, urinary flow-adjusted creatinine ratio, has been developed recently. This technique corrects for urinary flow rate and for urinary creatinine. ${ }^{17}$ Araki et al. ${ }^{17}$ reported that the concentrations of some metals and organic chemicals, including creatinine, were correlated with urinary flow rate. They therefore proposed a mathematical adjustment method that corrected for substance concentration to a standard urinary flow rate of $1 \mathrm{ml} / \mathrm{min}$, based on a log-log relationship between urinary flow rate and concentration of the studied substance. Unfortunately, on the basis of the results of the present study, this method did not improve the strength of association of soil arsenic with urinary arsenic. It was shown that neither urinary arsenic concentration nor urinary creatinine concentration was associated with urinary flow rate or urinary volume. This observation did not accord with the assumptions of this adjustment method. It should be noted that urine samples used in the present study were first morning voids. The time period prior to the voids most likely represented the elapsed time of the sleeping period. Thus, the variability in activity level and food and water consumption during this period was relatively stable, compared with that during any other time period of the day. Effects of diet, state of hydration, and diuresis on urinary flow were expected to be reduced. This might explain why this adjustment, based upon urinary volume or urinary flow rate, did not affect the association of urinary arsenic with environmental arsenic level.
In general, urinary concentration adjustments-recommended for some other chemical substances-are not necessary for urinary arsenic elimination, at least not for the young children's first morning void samples at the exposure levels seen in the present study. This suggests that the appropriateness of urinary concentration adjustments depends not only on the urinary flow but also on the substance-and quite likely on the sampling protocol.

Submitted for publication April 11, 1996; accepted for publication June 25, 1996.

Requests for reprints should be sent to Dr. Y. H. Hwang, National Taiwan University College of Public Health, Room 1453, \#1 Jen-Ai Road, Sec. 1, Taipei, Taiwan, ROC.

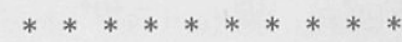

\section{References}

1. Enterline PE, Marsh GM, Esmen NA, et al. Some effects of cigarette smoking, arsenic, and $\mathrm{SO}_{2}$ on mortality among US copper smelter workers. J Occup Med 1987; 29(10):831-38.

2. Lee-Feldstein A. A comparison of several measures of exposure to arsenic. Am J Epidemiol 1989; 129:112-24.

3. Enterline PE, Henderson VL, Marsh GM. Exposure to arsenic and respiratory cancer-a reanalysis. Am J Epidemiol 1987; 125: 929-38.

4. Smith $A H$, Hopenhayn-Rich C, Bates MN, et al. Cancer risks from arsenic in drinking water. Environ Health Perspect 1992; 97:25967.

5. Roat JW, Wald A, Mendelow H, Pataki KI. Hepatic angiosarcoma associated with short-term arsenic ingestion. Am J Med 1982; 73 : 933-36.

6. Zaldivar R, Prumes L, Ghai GL. Arsenic dose in patients with cutaneous carcinomata and hepatic haemangio-endothelioma after environmental and occupational exposure. Arch Toxicol $1981 ; 47: 145-54$.

7. Chen Cl, Kuo TL, Wu MM. Arsenic and cancers. Lancet 1988; i:414-15.

8. Wu MM, Kuo TL, Hwang YH, Chen CJ. Dose-response relation between arsenic concentration in well water and mortality from cancers and vascular diseases. Am J Epidemiol 1989; 130:112332.

9. Risk Assessment Forum. Special report on ingested arsenic. Skin Cancer: Nutritional Essentiality. Washington, DC: US Environmental Protection Agency, 1988; EPA/625/3-87/013.

10. Chen CJ, Chuang YC, You SL, et al. A retrospective study on malignant neoplasms of bladder, lung and liver in Blackfoot Disease endemic area in Taiwan. Br J Cancer 1986; 53:399-405.

11. Crecelius EA. Changes in the chemical speciation of arsenic following ingestion by man. Environ Health Perspect 1977; 19:14750 .

12. Tam GKH, Charbonneau SM, Bryce F, et al. Metabolism of inorganic arsenic $\left({ }^{74} \mathrm{As}\right)$ in humans following oral ingestion. Toxicol Appl Pharmacol 1979; 50:319-22.

13. Buchet JP, Lauwerys R, Roels $\mathrm{H}$. Comparison of the urinary excretion of arsenic metabolites after a single oral dose of sodium arsenite, monomethylarsonate or dimethylarsinate in man. Int Arch Occup Environ Health 1981; 48:71-79.

14. American Conference of Governmental Industrial Hygienists $(\mathrm{ACGIH})$. Threshold Limit Values for Chemical Substance and Physical Agents and Biological Exposure Indices, 1995-1996. Cincinnati, OH: ACGIH, 1995.

15. Levine L, Fahy JP. Evaluation of urinary lead determinations. I. The significance of the specific gravity. J Ind Hyg Toxicol 1945; $27: 217-23$

16. Elkins HB, Pagnotto LD. Is the 24-hour urine sample a fallacy? Am Ind Hyg Assoc J 1965; 26:456-60. 
17. Araki S, Sata F, Murata K. Adjustment for urinary flow rate: an improved approach to biological monitoring. Int Arch Occup Environ Health $1990 ; 62: 471-77$.

18. Greenberg GN, Levine RJ. Urinary creatinine excretion is not stable: a new method for assessing urinary toxic substance concentrations. J Occup Med 1989; 31:832-38.

19. Elkins HB, Pagnotto LD, Smith HL. Concentration adjustments in urinalysis. Am Ind Hyg Assoc J 1974; 35:559-65.

20. Araki S. Effects of urinary volume on urinary concentrations of lead, delta-aminolaevulinic acid, coproporphyrin, creatinine, and total solutes. $\mathrm{Br}$ J Ind Med 1980; 37:50-54

21. Araki S, Murata K, Aono H, et al. Comparison of the effects of urinary flow on adjusted and non-adjusted excretion of heavy metals and organic substances in 'healthy' men. J Appl Toxicol 1986; $6: 245-51$

22. Atlantic Richfield Co. Environmental Action Plan for the Upper Clark Fork River Basin, Summer 1993. Los Angeles, CA: Atlantic Richfield, 1993; ARCOD-6010-B.

23. Que Hee S, Peace B, Clark S, et al. Evolution of efficient methods to sample lead sources, such as house dust and hand dust, in the homes of children. Environ Res 1985; 38:77-95.

24. Walters NJ, Estridge BH, Reynolds AP. Basic Medical Laboratory Techniques. 2nd ed. Albany, NY: Delmar Publisher, 1990:30910.

25. Henry RJ. Clinical Chemistry: Principles and Technique. 3rd ed. New York: Harper and Row, 1965.

26. Yamamoto $M$, Yasuda $M$, Yamamoto $Y$. Hydride-generation atomic absorption spectrometry coupled with flow injection analysis. Anal Chem 1985; 57:1382-85.

27. National Institute of Occupational Safety and Health (NIOSH). Arsenic in urine and air. In: NIOSH Manual of Analytical Methods. 2nd ed, vol 1. Cincinnati, OH: NIOSH, 1977; method no. P\&CAM 139.

28. Norin $\mathrm{H}$, Vahter $\mathrm{M}$. A rapid method for the selective analysis of total urinary metabolites of inorganic arsenic. Scand J Work En- viron Health $1981 ; 7: 38-44$.

29. Fox Software. FoxBASE+/Mac-Relational Database Management System. Perrysburg, OH: Fox Software; March 1991.

30. SAS. SAS/STAT User's Guide. Ver 6, 4th ed. Cary, NC: SAS Institute, 1989.

31. Slovis TL, Sty JR, Haller JO. Appendix 7: Glomerular Filtration Rate Using the Modified Gates Method-Normogram for the Determination of Body Surface Area of Children. Philadelphia, PA: WB Saunders, 1989; pp 58-59.

32. Binder S, Forney D, Kaye W, et al. Arsenic exposure in children living near a former copper smelter. Bull Environ Contam Toxicol 1987; 39:114-21.

33. Polissar L, Lowry-Coble K, Kalman DA, et al. Pathways of human exposure to arsenic in a community surrounding a copper smelter. Environ Res 1990; 53:29-47.

34. McVehil-Monnett Associates (MMA). Annual Aerometric Monitoring Report for the Anaconda Smelter Remedial Investigation/Feasibility Study Air Resources Program (July 1991-June 1992). Prepared for PTI Environmental Services and for ARCO Coal Company (MMA document control number 228-RI1-RTAN92).

35. Davis A, Ruby MV, Drexier J. Mineralogical Constraints on the Bioavailability of Arsenic in Smelter Impacted Soils. Boulder, CO: PTI Environmental Services, 1993. Presented at the International Conference on Arsenic Exposure and Health Effects; New Orleans, LA, 1993.

36. Freeman GB, Johnson JD, Killinger JM, et al. Bioavailability of arsenic in soil impacted by smelter activities following oral administration in rabbits. Fund Appl Toxicol 1993; 21(1):83-88.

37. Lauwerys RR. Industrial chemical exposure: Guidelines for Biological Monitoring. Davis, CA: Biomedical Publications, 1983.

38. Boeniger MF, Lowry LK, Rosenberg J. Interpretation of urine results used to assess chemical exposure with emphasis on creatinine adjustments: a review. Am Ind Hyg Assoc J 1993; 54(10):615-27. 
Copyright of Archives of Environmental Health is the property of Heldref Publications and its content may not be copied or emailed to multiple sites or posted to a listserv without the copyright holder's express written permission. However, users may print, download, or email articles for individual use. 